\title{
Use of the Cobra catheter for targeted temperature management during cardiopulmonary bypass in swine
}

Jared M. Slater, BA ${ }^{\mathrm{a}}$

Thomas A. Orszulak, MD

Kenton J. Zehr, MD

David J. Cook, MD

From the Divisions of Cardiothoracic Surgery $^{\mathrm{b}}$ and Cardiothoracic Anesthesiology, ${ }^{\mathrm{a}}$ Mayo Foundation and Mayo Clinic, Rochester, Minn.

Funding for this study was provided by Cardeon, Inc.

Received for publication July 27, 2001; revisions requested Sept 26, 2001; revisions received Oct 30, 2001; accepted for publication Nov 11, 2001.

Address for reprints: David J. Cook, MD, Mayo Foundation, 200 First St SW, Rochester, MN 55905 (E-mail: cook.david @ mayo.edu).

J Thorac Cardiovasc Surg 2002;123:936-42 Copyright $\odot 2002$ by The American Association for Thoracic Surgery

0022-5223/2002 \$35.00+0 $\quad \mathbf{1 2 / 1 / 1 2 1 4 9 8}$

doi:10.1067/mtc.2002.121498
Background: The purpose of this investigation was to determine whether temperatures of the aortic arch and descending aortic circulations could be controlled independently during cardiopulmonary bypass with a cannula possessing an endoaortic baffle (Cobra; Cardeon, Cupertino, Calif).

Methods: After Institutional Animal Care and Use Committee approval, 12 pigs weighing $60 \mathrm{~kg}$ were started on bypass through a sternotomy. A dual-lumen endoaortic cannula with a deployable baffle was used for arterial cannulation. Bypass was initiated at $37^{\circ} \mathrm{C}$, and control measurements were obtained. The baffle was then inflated with saline solution, segmenting blood flow along the greater and lesser curvatures of the aortic arch. Parallel heat exchangers were used to independently control temperature of the arch and descending aortic perfusates. Cerebral and systemic temperatures were recorded continuously.

Results: During cardiopulmonary bypass, mean flow and arterial pressure were maintained at 2.4 to $2.6 \mathrm{~L} \cdot \mathrm{min}^{-1} \cdot \mathrm{m}^{-2}$ and 60 to $70 \mathrm{~mm} \mathrm{Hg}$, respectively. With aortic flow distributed by the baffle, a $5^{\circ} \mathrm{C}$ temperature differential between brain $\left(30^{\circ} \mathrm{C}\right)$ and body $\left(35^{\circ} \mathrm{C}\right)$ was established in a mean of $5 \pm 2$ minutes. Mean brain and corporeal temperatures of $27^{\circ} \mathrm{C}$ and $35^{\circ} \mathrm{C}$ were then maintained over 60 minutes. Relative to control, internal jugular and inferior vena cava oxygen saturations increased during targeted temperature control with the device.

Conclusions: The Cobra cannula allows for independent control of brain and body temperature while providing satisfactory hemodynamics. Application of this temperature management strategy may offer cerebral protection and the advantages of warm systemic bypass temperature.

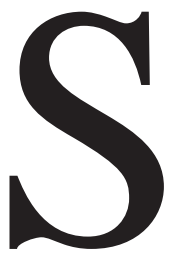

ince the development of cardiopulmonary bypass (CPB), temperature management has been evolving. ${ }^{1}$ In the absence of heat exchangers, early bypass was conducted at relative normothermia. Thereafter, whole-body hypothermia became standard practice until the 1990s, when there was a shift to warmer bypass temperatures. Over the last 5 years, systemic temperature for much of adult cardiac operations has settled out near $33^{\circ} \mathrm{C}$ to $35^{\circ} \mathrm{C}$. The reasons for these changes are complex. Warmer bypass temperatures may be associated with hemodynamic benefits resulting from the combination of better rhythm, ${ }^{1-6}$ higher cardiac output, and lower systemic vascular resistance., ${ }^{3,6,7}$ Furthermore, because of the elimination of the need for cooling and rewarming, the warm technique can be associated with shorter $\mathrm{CPB}$ times. ${ }^{8-10}$ Additionally, although not all reports are in agreement, postoperative bleeding may be less, ${ }^{11,12}$ and postoperative temperature afterdrop ${ }^{13,14}$ is probably reduced. Finally, respiratory demands in the intensive care unit may be less, and this has been shown by some authors to be associated with shorter times to extubation..$^{7,15}$ 


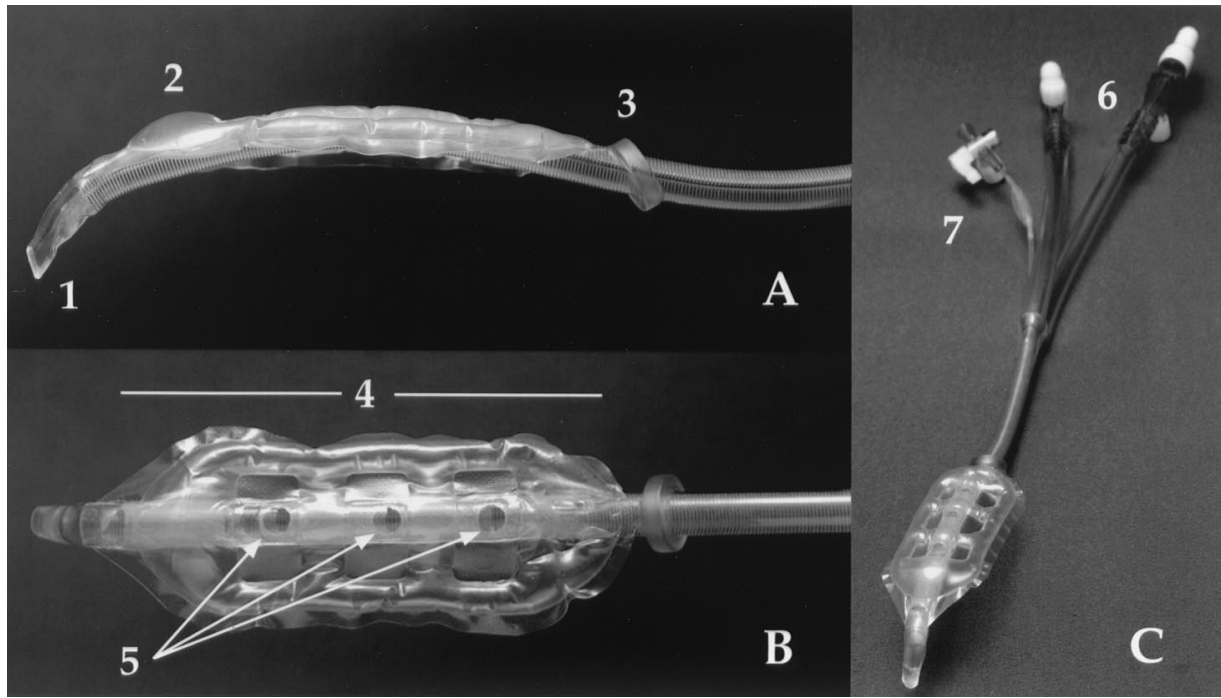

Figure 1. Photograph of the Cobra catheter. A, Endoaortic portion in profile demonstrating the descending aorta perfusion port (1), the wing pillow (2) that minimizes distal flow around the baffle, and the sewing ring (3), which prevents device migration. B, Endoaortic portion (top view) illustrating cannula baffle or wing (4) and arch perfusion ports (5). C, Cobra cannula ex vivo demonstrating 2 proximal connection ports (6) and pilot balloon (7) for baffle inflation.

Although warm bypass temperatures have found acceptance, ${ }^{16-18}$ there are concerns over the neurologic effects of this technique ${ }^{9,19}$ because hypothermia offers cerebral protection from ischemia. ${ }^{20}$ As such, the ability to selectively control cerebral temperature independent of systemic temperature may offer unique advantages, allowing for both the potential cardiac, respiratory, and hematologic effects of warm body temperature and the brain protection offered by cerebral hypothermia.

A variety of techniques have been applied experimentally and clinically to provide more selective hypothermic cerebral protection. These have included topical cooling, antegrade and retrograde cerebral perfusion, and isolation of perfusion to the arch and descending aorta. ${ }^{21-23}$ The innovation we examine here is segmentation of flow in the aortic arch along the greater and lesser curvatures by means of a deployable baffle and, through that, independent temperature control of the arch and descending aortic circulations.

\section{Materials and Methods}

After review and approval by the Institutional Animal Care and Use Committee, fasting pigs $(\mathrm{n}=12)$ weighing 55 to $65 \mathrm{~kg}$ were studied. Body surface area was determined by using a veterinary table of values. Pigs were premedicated with tamsulosin (Telazol) $(4 \mathrm{mg} / \mathrm{kg})$ and xylazine $(2 \mathrm{mg} / \mathrm{kg})$ intramuscularly. Anesthesia was induced with $2 \%$ halothane in oxygen by mask, and the trachea was intubated. Peripheral intravenous access was secured, and muscle relaxation was obtained with pancuronium $(0.2 \mathrm{mg} / \mathrm{kg}$ intravenously). Ventilation was controlled to maintain $\mathrm{PaCO}_{2}$ at 35 to $40 \mathrm{~mm} \mathrm{Hg}$ and $\mathrm{a} \mathrm{PaO}_{2}$ at greater than $150 \mathrm{~mm} \mathrm{Hg}$. Anesthesia was maintained with $0.5 \%$ to $1 \%$ halothane and a continuous intravenous infusion of fentanyl $\left(0.7 \mu \mathrm{g} \cdot \mathrm{kg}^{-1} \cdot \mathrm{min}^{-1}\right)$ and ketamine $\left(28 \mu \mathrm{g} \cdot \mathrm{kg}^{-1} \cdot \min ^{-1}\right)$. Pancuronium $\left(0.3 \mu \mathrm{g} \cdot \mathrm{kg}^{-1}\right.$. $\min ^{-1}$ ) was administered to provide continuous muscle relaxation.

Four-inch 18-gauge catheters were surgically inserted into the right femoral and left axillary arteries for blood sampling and mean arterial blood pressure (MAP) monitoring of the corporeal and arch circulations, respectively. Catheters were also placed into the left internal jugular vein (threaded cephalad to the base of the skull) and into the inferior vena cava (IVC) from the right femoral vein.

A wire thermocouple was advanced $20 \mathrm{~cm}$ into the IVC through the femoral vein catheter. Brain temperature was monitored with a needle thermocouple placed $2 \mathrm{~cm}$ into the brain through a parietal skull burr hole. The hole was then filled with Surgicel, and the scalp was closed. Temperatures were recorded each minute by using a multichannel recording system (TM-12; Physitemp Instruments Inc, Clifton, NJ) and downloaded to a laptop computer.

Blood gases and oxygen saturation (IL-BGE Analyzer and IL 482 Co-Oximeter; Instrumentation Laboratories, Inc, Boston, Mass) from the femoral artery, IVC, and internal jugular vein were obtained at each study period. Alpha-stat management was used at all times when the perfusate was less than $37^{\circ} \mathrm{C}$. Additionally, blood gas data were continuously monitored during CPB by using an in-line analyzer (CDI 400; Cardiovascular devices, Inc, Tustin, Calif). A Delphin II (Sarns; 3M, Ann Arbor, Mich) ultrasonic flow probe measured $\mathrm{CPB}$ flows in the arch and corporeal circulation.

\section{Cannulation and CPB}

The heart was approached through a sternotomy, and the pericardium was reflected. A dual-lumen 24F cannula (Cobra; Cardeon Inc, Cupertino, Calif), with an inflatable baffle capable of segment- 


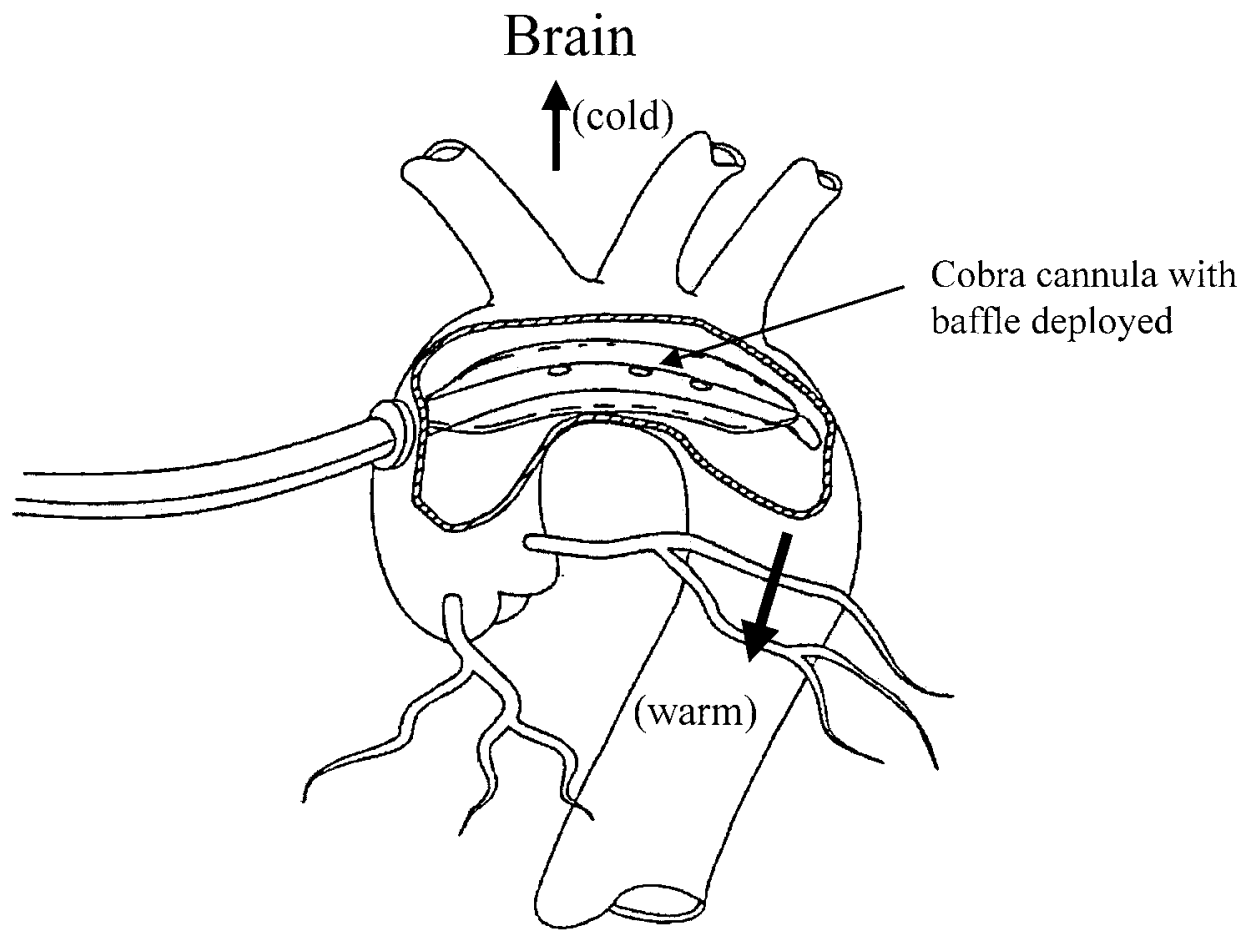

Figure 2. Schematic of the Cobra cannula in situ. Perfusion ports for the arch vessels are cephalad to the inflatable baffle, and the port supplying the descending aorta is distal to the baffle.

TABLE 1. Physiologic data

\begin{tabular}{|c|c|c|c|c|c|c|}
\hline & $\begin{array}{c}\text { Arch flow } \\
\left(\mathrm{L} \cdot \mathrm{min}^{-1} \cdot \mathrm{m}^{-2}\right)\end{array}$ & $\begin{array}{l}\text { Distal aortic flow } \\
\left(\mathrm{L} \cdot \mathrm{min}^{-1} \cdot \mathrm{m}^{-2}\right)\end{array}$ & $\begin{array}{c}\text { MAP }_{a x} \\
(\mathrm{~mm} \mathrm{Hg})\end{array}$ & $\begin{array}{l}\text { MAP }_{\text {fem }} \\
(\mathrm{mm} \mathrm{Hg})\end{array}$ & $\begin{array}{c}\text { Hemoglobin } \\
\text { (g/dL) }\end{array}$ & $\begin{array}{c}\mathrm{PaCO}_{2} \\
(\mathrm{~mm} \mathrm{Hg})\end{array}$ \\
\hline $\begin{array}{l}\text { Before CPB } \\
\text { CPB }\end{array}$ & & & $76 \pm 14$ & $76 \pm 14$ & $11.1 \pm 1.1$ & $35 \pm 4$ \\
\hline $\begin{array}{l}\text { Control } \\
\text { TTM } \\
\text { After TTM }\end{array}$ & $\begin{array}{l}1.1 \pm 0.3 \\
0.8 \pm 0.2 \dagger \\
1.0 \pm 0.3\end{array}$ & $\begin{array}{l}1.6 \pm 0.3^{*} \\
1.5 \pm 0.3^{*} \\
1.5 \pm 0.3^{*}\end{array}$ & $\begin{array}{l}68 \pm 11 \\
67 \pm 8 \\
65 \pm 8\end{array}$ & $\begin{array}{l}65 \pm 8 \\
59 \pm 9 * \\
65 \pm 8\end{array}$ & $\begin{array}{l}9.3 \pm 0.8 \dagger \\
9.1 \pm 1.0 \dagger \\
9.0 \pm 1.2 \dagger\end{array}$ & $\begin{array}{l}37 \pm 3 \\
37 \pm 3 \\
38 \pm 2\end{array}$ \\
\hline
\end{tabular}

Ao, Aorta; $M A P_{a x}$ axillary artery MAP; $M A P_{\text {fem, }}$ femoral artery MAP.

${ }^{*} P<.05$ between arch and distal aorta by means of paired $t$ test after 2-way repeated-measures analysis of variance.

$\dagger P<.05$ within groups by means of paired $t$ test after 2-way repeated-measures analysis of variance.

ing the greater and lesser curvatures of the aortic arch, was inserted through a standard ascending aortotomy (Figure 1). The catheter was inserted until the depth stop on the catheter was against the adventitia of the ascending aorta (Figure 2). Venous drainage to the extracorporeal circuit with a 2 -stage $40 \mathrm{~F}$ cannula was placed through the atrial appendage.

The bypass circuit was primed with $1500 \mathrm{~mL}$ of crystalloid solution. Blood from the venous cannula drained into a single hard-shell cardiotomy reservoir and was pumped by means of a centrifugal pump (Sarns, 3M) through a combined heat exchangeroxygenator (Bentley Univox, Irvine, Calif). Distal to the oxygenator, a bifurcation in the tubing allowed warm oxygenated blood to be delivered either to the cannula port supplying the distal (descending aorta) lumen of the aortic cannula or to a second heat exchanger (HE-30 GOLD; Bentley, Irvine, Calif) used to cool the aortic arch perfusate. The hypothermic aortic arch perfusate was subsequently delivered to the proximal ports of the aortic cannula.

Bypass was divided into 3 phases. The first period was control. During this time, blood gases, total CPB flow $\left(2.4-2.6 \mathrm{~L} \cdot \mathrm{min}^{-1}\right.$ $\left.\cdot \mathrm{m}^{-2}\right)$, MAP $(60-70 \mathrm{~mm} \mathrm{Hg})$, and temperature $\left(36^{\circ} \mathrm{C}-38^{\circ} \mathrm{C}\right)$ were stabilized for at least 15 minutes. The second bypass period was targeted temperature management (TTM). During TTM, the baffle was inflated with saline solution until adequate filling was indicated by a pilot balloon. The secondary heat exchanger was then activated, and cooling continued until brain temperature was reduced by $8^{\circ} \mathrm{C}$ to $10^{\circ} \mathrm{C}$, while at the same time maintaining a corporeal temperature of $34^{\circ} \mathrm{C}$ or greater. This condition was maintained for 60 minutes, after which the baffle was deflated, cooling of the arch heat exchanger was stopped, and arch circulation was allowed to warm (post-TTM period). 
We determined the time required to reduce cerebral temperature $5^{\circ} \mathrm{C}$ or greater relative to IVC temperature and the duration of time that the temperature differential was maintained. Duration of time after TTM that cerebral temperature remained less than $35^{\circ} \mathrm{C}$ was also determined.

\section{Data Analysis}

Changes in physiologic variables during the 3 study periods were assessed by using 2-way repeated-measures analysis of variance. When this test identified significance, a paired $t$ test was used to determine significance at each study period. Temperatures during stable TTM are expressed as a time-weighted average. Data are expressed as means $\pm \mathrm{SD}$.

\section{Results}

The mean animal weight and body surface area were $60.5 \pm$ $3.1 \mathrm{~kg}$ and $1.5 \pm 0.1 \mathrm{~m}^{2}$, respectively.

Physiologic data at each study period are provided in Table 1. Total CPB flow during the control bypass period was $2.6 \pm 0.5 \mathrm{~L} \cdot \min ^{-1} \cdot \mathrm{m}^{-2}$, and MAP in the axillary and femoral arteries was $68 \pm 11$ and $65 \pm 8 \mathrm{~mm} \mathrm{Hg}$, respectively (Table 1). During this time, the internal jugular $\left(\mathrm{SjvO}_{2}\right)$ and IVC venous oxygen saturations $\left(\mathrm{SvO}_{2}\right)$ differed $(71 \% \pm 11 \%$ and $55 \% \pm 8 \%$, respectively; $P<.001$; Figure 3). During bypass, the hemoglobin concentration was reduced relative to the prebypass period (Table 1).

When the cannula baffle was inflated, the mean flow through the arch port of the aortic cannula was $0.8 \pm 0.2 \mathrm{~L}$ $\cdot \min ^{-1} \cdot \mathrm{m}^{-2}$, and flow through the descending aortic port was $1.5 \pm 0.3 \mathrm{~L} \cdot \min ^{-1} \cdot \mathrm{m}^{-2}$ (Table 1 ). The mean total flow during TTM was $2.4 \pm 0.4 \mathrm{~L} \cdot \mathrm{min}^{-1} \cdot \mathrm{m}^{-2}$. During TTM, the blood pressure in the arch circulation was greater than that in the corporeal circulation (67 vs $59 \mathrm{~mm} \mathrm{Hg}$, respectively; $P=.037$; Table 1 ).

Changes in brain and IVC temperatures during CPB are illustrated in Figure 4. At the time TTM was initiated, the mean brain and IVC (corporeal) temperatures were $36.6^{\circ} \mathrm{C} \pm 1.0^{\circ} \mathrm{C}$ and $36.5^{\circ} \mathrm{C} \pm 1.2^{\circ} \mathrm{C}$, respectively. The mean time to reach a $5^{\circ} \mathrm{C}$ differential between the 2 circulations was $5 \pm 2$ minutes. During TTM, the brain underwent a mean $9^{\circ} \mathrm{C}$ temperature decrease, whereas the IVC (corporeal) temperature decreased $2^{\circ} \mathrm{C}$. The time-weighted temperature averages for brain and corporeal circulations during TTM were $26.8^{\circ} \mathrm{C} \pm 2.9^{\circ} \mathrm{C}$ and $35.0^{\circ} \mathrm{C} \pm 1.5^{\circ} \mathrm{C}$, respectively. Independent temperature control was maintained for $60 \pm 11$ minutes.

During TTM, there was a significant increase in the $\mathrm{SjvO}_{2}$ compared with that in the control period $(90 \% \pm 12 \%$ vs $71 \% \pm 11 \%, P=.004)$. Furthermore, the mean $\mathrm{SjvO}_{2}$ during TTM was significantly greater than the $\mathrm{SvO}_{2}$ measured in the IVC $(P<.0001$, Figure 3$)$.

After 60 minutes, the baffle was deflated, and cooling of the arch perfusate was stopped. The brain rewarmed to a mean temperature of $35.4^{\circ} \mathrm{C} \pm 2.0^{\circ} \mathrm{C}$ over $27.2^{\circ} \mathrm{C} \pm 13.6^{\circ} \mathrm{C}$

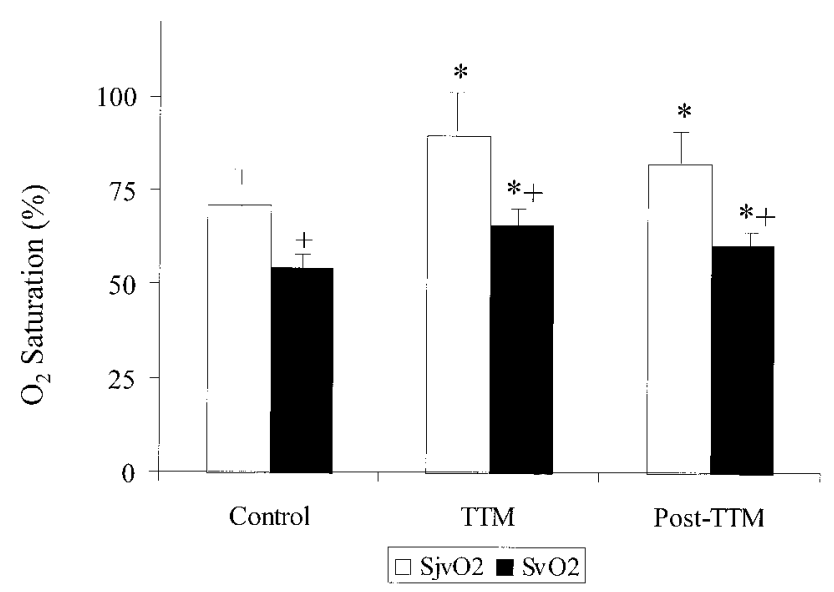

Figure 3. $\mathrm{Sjv}_{2}$ and IVC oxygen saturation $\left(\mathrm{Sv}_{2}\right)$ during each CPB study period (control, before TTM). Values are means \pm SD ( $\mathrm{n}=12$ ). ${ }^{*} P<.05$ and $+P<.05$ between study periods by means of paired $\boldsymbol{t}$ test after 2-way repeated-measures analysis of variance. $\$ P<.001$ between $\mathrm{Sjvo}_{2}$ and $\mathrm{Sjvo}_{2}$ by means of paired $t$ test after 2-way repeated-measures analysis of variance when indicated.

minutes. Cerebral hyperthermia was not observed in any animal. Brain temperature remained below $35^{\circ} \mathrm{C}$ for $62 \% \pm$ $15 \%$ of this period, whereas the $\mathrm{SjvO}_{2}$ remained elevated relative to the control period ( $P=.003$, Figures 3 and 4). During all periods, the $\mathrm{Sjvo}_{2}$ was greater than the $\mathrm{SvO}_{2}$ (Figure 2). Systemic venous oxygen saturation was also higher after TTM $(61 \% \pm 5 \%)$ than in the control period $(55 \% \pm 8 \%, P<.05)$.

\section{Discussion}

In this report we demonstrate that selective cerebral hypothermia $\left(27^{\circ} \mathrm{C}\right)$ and simultaneous warm body temperature $\left(35^{\circ} \mathrm{C}\right)$ can be readily achieved with the Cobra aortic cannula.

The device tested here evolved from an earlier one designed to independently control arch and descending aortic temperatures. ${ }^{23}$ The earlier design achieved isolation of the arch and descending aorta by means of a balloon inflated in the proximal descending aorta. In contrast, even partial aortic occlusion is not necessary with the Cobra device. Segmentation of aortic flow and temperature control is achieved with a baffle that inflates orthogonal to the axis of the transverse arch (Figure 5). This minimizes contact with the aortic wall and effectively isolates flow along the lesser and greater curvatures of the arch. Perfusion ports cephalad to the baffle perfuse the arch vessels, and a distal and caudad port supplies the descending aorta.

The CPB circuit requires little modification to achieve TTM. A single pump head is used, and a second heat exchanger is introduced to control arch temperature. Aortic inflow is provided by $1 / 4$-inch and $3 / 8$-inch lines connected, 


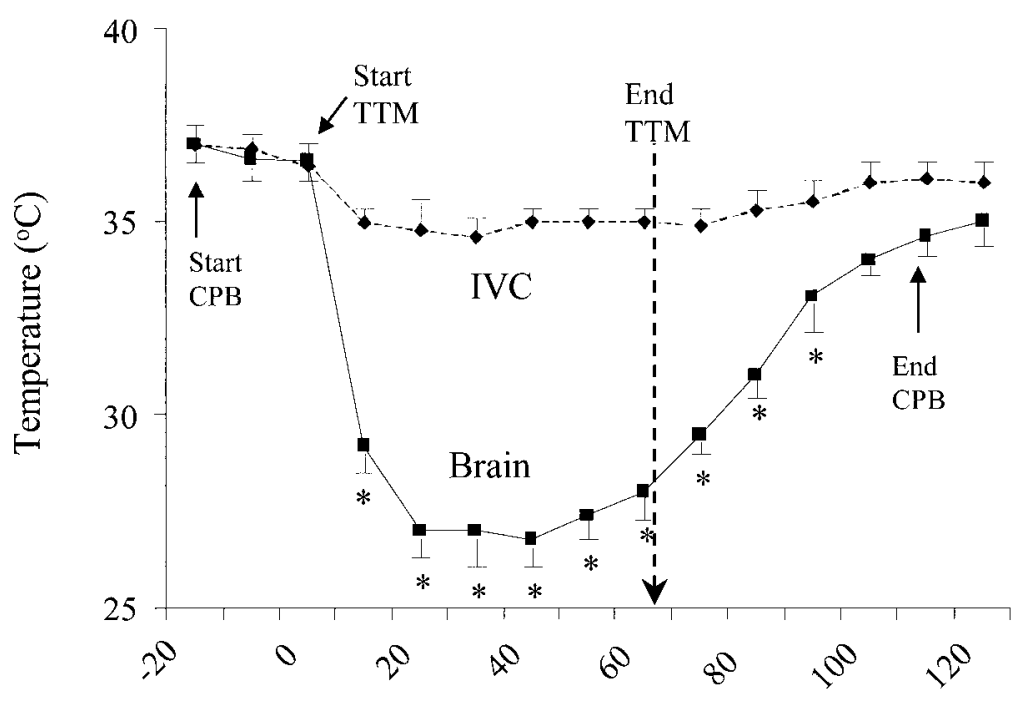

Time (min)

\begin{abstract}
Figure 4. Brain (filled squares) and IVC (filled diamonds) temperature over the 3 phases of CPB. At time 0, targeted TTM was initiated. * $P<.05$, brain versus IVC temperature by means of paired $t$ test after 2 -way repeated-measures analysis of variance. Time-weighted mean $\pm S D$ is given at 10 -minute intervals $(n=12)$.
\end{abstract}

respectively, to the arch and descending aortic ports of the device (Figure 1).

Probably the most important practical question raised by this modification of CPB practice is how much flow should be directed to the arch and descending aortic circulations when using this device. In this experiment (and in initial clinical trials) a single pump head was used, and therefore flow to the arch and descending aortic circulations is determined by the relative resistance of the circuit limbs and the vascular resistance in those organ beds. This allows autoregulatory mechanisms to determine perfusion of the arch and descending aortic circulations. Furthermore, the intrinsic resistance of the system was designed to achieve a high arch flow relative to the body surface area perfused. This accounts for the slightly higher MAP in the arch circulation during TTM. A second critical design feature is that the baffle is not occlusive proximally. As such, the relatively high perfusion directed to the arch vessels overflows around the baffle in the proximal aorta. This overflow has important effects. The mixing of cold and warm blood in the proximal aorta slightly cools the blood delivered down the descending aorta. This accounts for the $2^{\circ} \mathrm{C}$ to $3^{\circ} \mathrm{C}$ of cooling demonstrated in the IVC temperature. Hemodynamically, the nonocclusive design of the device also eliminates the question as to how much flow should be directed to the arch vasculature because arch perfusion is high and because the arch cannot be overperfused as a result of the proximal overflow that occurs. The adequacy of this design was indicated in this experiment by means of the very rapid reduction in brain temperature seen with initiation of TTM and the large increases in cerebral venous oxygenation saturations demonstrated.

A second primary consideration with any endoaortic device, whether it is an intra-aortic balloon pump, emboli trap, or Port-Access (Heartport Inc, Redwood City, Calif) cannula, is the potential risk of embolization with device placement. Very recently, this device has been used clinically. In that investigation device application was contingent on the assessment of aortic atherosclerosis with transesophageal echocardiography, with grade IV disease as an exclusion criteria. Although severe atheromatous disease may be a relative contraindication to the use of any aortic device, severe disease is only seen in $2 \%$ to $17 \%$ of patients (depending on technique and grading scale). ${ }^{24-26}$ As such, this type of device could have application in the majority of adults undergoing cardiac surgery.

In addition to being able to independently control brain and body temperature during bypass, this device has a second very unique design effect. The continuous overflow from the greater curvature of the arch to the lesser curvature around the proximal aorta continuously washes emboli generated in the proximal aorta along the lesser curvature and down the descending aorta. This protects the brain from embolization. In an experimental swine model with $100-\mu \mathrm{m}$ microspheres injected into the aortic root, embolization to the brain was reduced approximately $90 \%$ with the Cobra device, even in the absence of cerebral cooling. ${ }^{27}$ A greater 


\section{Brachiocephalic, carotid, subclavian arteries}

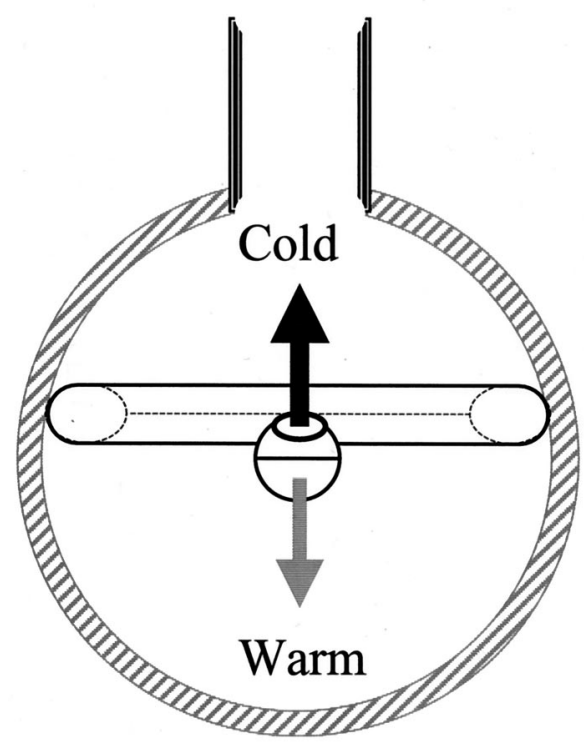

Figure 5. Schematic of the Cobra device in the transverse thoracic aorta viewed in cross-section. When inflated with saline solution, the wing is oriented perpendicular to the axis of the transverse thoracic aorta, segmenting flow along the greater and lesser curvatures of the aortic arch.

reduction in brain embolization would be predicted if cerebral cooling was combined with the effect of the baffle.

The use of this device late in bypass also deserves comment. During standard bypass with induced hypothermia, cerebral hyperthermia is relatively common during rewarming. ${ }^{28}$ This occurs because the warmest blood enters the aorta just proximal to the carotid origins and because cerebral blood flow is high. This can result in cerebral oxygenation stress, ${ }^{29,30}$ and it is clear that small degrees of hyperthermia can greatly aggravate neurologic injury when ischemia occurs. ${ }^{20}$ In this study mild cerebral hypothermia and favorable cerebral oxygen balance persisted after deflation of the baffle, even when cooling of the arch limb of the circuit was stopped. However, greater cerebral benefit might result from continued perfusion of the arch with a mildly hypothermic perfusate until closer to the end of CPB.

A device of this design can extend the range of possibilities for temperature management during CPB. The combination of cerebral hypothermia with a body temperature of about $34^{\circ} \mathrm{C}$ to $35^{\circ} \mathrm{C}$ may offer the best possible circumstances for optimizing neurologic and cardiovascular outcomes. This device is unique in that regard. A large randomized clinical trial determining the effect of this device on neurologic, neurocognitive, and cardiopulmonary outcomes has been initiated.

\section{References}

1. Cook DJ. Changing temperature management for cardiopulmonary bypass. Anesth Analg. 1999;88:1254-71.

2. Gozal Y, Glantz L, Luria MH, Milgalter E, Shimon D, Drenger B. Normothermic continuous blood cardioplegia improves electrophysiologic recovery after open heart surgery. Anesthesiology. 1996;84: 1298-306.

3. Birdi I, Regragui I, Izzat MB, Bryan AJ, Angelini GD. Influence of normothermic systemic perfusion during coronary artery bypass operations: a randomized prospective study. J Thorac Cardiovasc Surg. 1997; 114:475-81.

4. Lichtenstein SV, Ashe KA, El Dalati H, Cusimano RJ, Panos A, Slutsky AS. Warm heart surgery. J Thorac Cardiovasc Surg. 1991; 101:269-74.

5. Lichtenstein SV, Abel JG, Salerno TA. Warm heart surgery and results of operation for recent myocardial infarction. Ann Thorac Surg. 1991;52:455-60.

6. Christakis GT, Koch JP, Deemar KA, Fremes SE, Sinclair L, Chen E, et al. A randomized study of the systemic effects of warm heart surgery. Ann Thorac Surg. 1992;54:449-59.

7. Lehot JJ, Villard J, Piriz H, Philbin DM, Carry P-Y, Gauquelin G, et al. Hemodynamic and hormonal responses to hypothermic and normothermic cardiopulmonary bypass. J Cardiovasc Vasc Anesth. 1992; 6:132-9.

8. Tonz M, Mihaljevic T, von Segesser LK, Schmid ER, Joller-Jemelka HI, Pei P, et al. Normothermia versus hypothermia during cardiopulmonary bypass: a randomized, controlled trial. Ann Thorac Surg. 1995;59:137-43

9. Craver JM, Bufkin BL, Weintraub WS, Guyton RA. Neurologic events after coronary bypass grafting: further observations with warm cardioplegia. Ann Thorac Surg. 1995;59:1429-34.

10. Plourde G, Leduc AS, Morin JE, DeVarennes B, Latter D, Symes J, et al. Temperature during cardiopulmonary bypass for coronary artery operations does not influence postoperative cognitive function: a prospective, randomized trial. J Thorac Cardiovasc Surg. 1997;114: 123-8.

11. Schmied H, Kurz A, Sessler DI, Kozek S, Reiter A. Mild hypothermia increases blood loss and transfusion requirements during total hip arthroplasty. Lancet. 1996;347:289-92.

12. Boldt J, Knothe C, Zickmann B, Bill S, Dapper F, Hempelmann G. Platelet function in cardiac surgery: influence of temperature and aprotinin. Ann Thorac Surg. 1993;55:652-8.

13. Rajek A, Lenhardt R, Sessler DI, Kurz A, Laufer G, Christensen R, et al. Tissue heat content and distribution during and after cardiopulmonary bypass at $31^{\circ} \mathrm{C}$ and $27^{\circ} \mathrm{C}$. Anesthesiology. 1998;88:1511-8.

14. Ramsay JG, Ralley FE, Whalley DG, DelliColli P, Wynands JE. Site of temperature monitoring and prediction of afterdrop after open heart surgery. Can Anaesthetists Soc J. 1985;32:607-12.

15. Sladen RN. Temperature and ventilation after hypothermic cardiopulmonary bypass. Anesth Analg. 1985;64:816-20.

16. The Warm Heart Investigators. Randomised trial of normothermic versus hypothermic coronary bypass surgery. Lancet. 1994;343:55963.

17. Mora CT, Henson MB, Weintraub WS, Murkin JM, Martin TD, Craver JM, et al. The effect of temperature management during cardiopulmonary bypass on neurologic and neuropsychologic outcomes in patients undergoing coronary revascularization. $J$ Thorac Cardiovasc Surg. 1996;112:514-22.

18. Wong BI, McLean RF, Naylor CD, Snow WG, Harrington EM, Gawel MJ, et al. Central-nervous-system dysfunction after warm or hypothermic cardiopulmonary bypass. Lancet. 1992;339:1383-4.

19. Martin TD, Craver JM, Gott JP, Weintraub WS, Ramsay J, Mora CT, et al. Prospective, randomized trial of retrograde warm blood cardioplegia: myocardial benefit and neurologic threat. Ann Thorac Surg. 1994;57:298-304.

20. Minamisawa H, Smith ML, Siesjo BK. The effect of mild hyperthermia and hypothermia on brain damage following 5,10 , and 15 minutes of forebrain ischemia. Ann Neurol. 1990;28:26-33. 
21. Lytle BW, McCarthy PM, Meaney KM, Stewart RW, Cosgrove DM III. Systemic hypothermia and circulatory arrest combined with arterial perfusion of the superior vena cava: effective intraoperative cerebral protection. J Thorac Cardiovasc Surg. 1995;109:738-43.

22. Juvonen T, Zhang N, Wolfe D, Weisz DJ, Bodian CA, Shiang HH, et al. Retrograde cerebral perfusion enhances cerebral protection during prolonged hypothermic circulatory arrest: a study in a chronic porcine model. Ann Thorac Surg. 1998;66:38-50.

23. Boston US, Sungurtekin H, McGregor C, Macoviak J, Cook DJ. Differential perfusion: a new technique for isolated brain cooling during cardiopulmonary bypass. Ann Thorac Surg. 2000;69:1346-50.

24. Mills NL, Everson CT. Atherosclerosis of the ascending aorta and coronary artery bypass. Pathology, clinical correlates, and operative management. J Thorac Cardiovasc Surg. 1991;102:546-53.

25. Montgomery DH, Ververis JJ, McGorisk G, Frohwein S, Martin RP, Taylor WR. Natural history of severe atheromatous disease of the thoracic aorta: a transesophageal echocardiographic study. J Am Coll Cardiol. 1996;27:95-101.
26. Davila-Roman VG, Phillips KJ, Daily BB, Davila RM, Kouchoukos NT, Barzilai B. Intraoperative transesophageal echocardiography and epiaortic ultrasound for assessment of atherosclerosis of the thoracic aorta. J Am Coll Cardiol. 1996;28:942-7.

27. Cook DJ, Zehr KJ, Orszulak TA, Slater JM. Profound reduction in brain embolization using an endoaortic baffle during bypass in swine. Ann Thorac Surg. 2002;73:198-202.

28. Cook DJ, Orszulak TA, Daly RC, Buda DA. Cerebral hyperthermia during cardiopulmonary bypass in adults. J Thorac Cardiovasc Surg. 1996;111:268-9.

29. Cook DJ, Oliver WC Jr, Orszulak TA, Daly RC. A prospective, randomized comparison of cerebral venous oxygen saturation during normothermic and hypothermic cardiopulmonary bypass. $J$ Thorac Cardiovasc Surg. 1994;107:1020-9.

30. Croughwell ND, Frasco P, Blumenthal JA, Leone BJ, White WD, Reves JG. Warming during cardiopulmonary bypass is associated with jugular bulb desaturation. Ann Thorac Surg. 1992;53:827-32.

\section{Availability of Journal back issues}

As a service to our subscribers, copies of back issues of The Journal of Thoracic and Cardiovascular Surgery for the preceding 5 years are maintained and are available for purchase from Mosby until inventory is depleted. Please write to Mosby, Subscription Customer Service, 6277 Sea Harbor Dr, Orlando, FL 32877, or call $800-654-2452$ or $407-345-4000$ for information on availability of particular issues and prices. 